\title{
Metacognitive Awareness in Language Learning Strategies and Strategy Instruction in CLIL Settings
}

\author{
Yolanda Ruiz de Zarobe ${ }^{1} \&$ Simone Smala ${ }^{2}$ \\ ${ }^{1}$ University of the Basque Country, UPV/EHU, ${ }^{2}$ The University of Queensland \\ yolanda.ruizdezarobe@ehu.eus; s.smala@uq.edu.au
}

\begin{abstract}
This article contrasts two studies that focus on language learning strategies (Study 1) and strategy instruction (Study 2) in CLIL programs. Drawing from the literature on language learning strategies and strategy instruction, we propose a theoretical framework that takes into account metacognitive awareness as a useful concept to capture the interrelatedness of teaching, learning and using language learning strategies in CLIL. We approach metacognitive awareness from two positions: 1) as a concept that describes self-regulated learning in students and constitutes one of the important areas of language learning strategies (metacognitive strategies), and 2) as a key concept when describing the decisions teachers make in their pedagogical planning and implementation, including when deciding on which language learning strategies to single out for instruction, and how to instruct these. We understand these two positions as interrelated and "speaking to each other", scaffolding the learning processes through focused attention to vocabulary and language structures needed for content message and understanding. For future research, we propose a focus on CLIL teachers' reflective cycles that take into account students' prior knowledge (e.g., cognates, language learning strategies learnt in mainstream language classes, understanding of subject-specific concepts in native language), to build up a repertoire of language learning strategies and strategy instruction that supports the processes when integrating language and content learning.
\end{abstract}

Keywords: CLIL, language learning strategies, strategy instruction, metacognitive awareness

This work is licensed under the Creative

Commons Attribution-ShareAlike 4.0

International agreement (CC BY-SA 4.0).

http://creativecommons.org/licenses/by-sa/4.0/
Journal for the Psychology of Language Learning ISSN: 2642-7001. https://doi.org/10.52598/jp11/2/2/3

Volume 2, Issue 2, pp. 20-35

(Special Issue: The Psychology of Teaching and Learning Content \& Language) 
In a recent special issue on Language Learning Strategies (LLS), Pawlak and Oxford (2018) call for more research into language strategy instruction, to "potentially enhance the efficacy of instruction in LLS" (p. 530). Furthermore, the authors identify content-based language instruction as a "setting in which empirical investigations of LLS should gain momentum in response to the ongoing changes in how second and foreign languages are taught and learned" ( $p$. 530). Oxford (1990) established a comprehensive inventory of LLS, named the Strategy Inventory for Language Learning (SILL). She divided LLS into two main areas: direct (memory, cognitive, and compensation strategies) and indirect (metacognitive, affective, and social strategies). However, Cohen and Wang (2018) have argued that strategies tended to be labelled in a relatively monolithic way with regard to their function (i.e., cognitive, metacognitive, social, and affective) and at any micromoment a given strategy may assume more than one function. We are particularly interested in the interplay of cognitive and metacognitive LLS and, furthermore, the possible interplay of students using such cognitive and metacognitive strategies for learning language and content in CLIL settings, and teacher instructing their students to do so across language and content integration.

As an enabler for this endeavor, we present here a crossanalysis of two existing studies in CLIL. CLIL stands for Content and Language Integrated Learning and refers to teaching subjects such as science, history and geography to students through a foreign language. One of the studies we draw on is a study conducted by Ruiz de Zarobe (the first author of this article) and Zenotz (2018); their article, "How does strategy instruction affect reading competence over time?", was singled out as a case pertinent study by Pawlak and Oxford (2018, p. 530). The study looks at reading strategy instruction in a CLIL classroom in Spain, with the focus on students' competence. The second article (Smala, 2014) draws on a study into experiences of CLIL teachers in Australia, with a focus on their pedagogical work and decision-making. We offer here a novel interpretation of both studies, in an effort to pave the way towards further studies in language learning strategies and language strategy instruction in CLIL settings that might consider such variables as the "context in which it is undertaken, the types of strategies that are taught, the way in which it is conducted" (Pawlak \& Oxford, 2018, p. 529).
CLIL programs are now a widespread phenomenon in Europe, and increasingly also in countries like Australia and Japan. Recent years have seen a global rise of CLIL as a pedagogical approach in bilingual programs and as a teaching activity in second language classrooms, with publications exploring CLIL in Asia (e.g., Lin, 2016), South America (e.g., Banegas, 2011) and Africa (e.g., Webb, 2010), as well as the long tradition of researching contentbased instruction in the United States (e.g., Snow \& Brinton, 2017). It is therefore an apt time to utilize insights from many diverse contexts to conduct "eagle-eye" studies - at the same time broad in contextual scope (like an eagle from above) and focused in its topic (like an eagle and its prey). We have chosen here to focus on language learning strategies and language strategy instruction, and understand this field as closely related to such concepts as metacognitive awareness, self-regulated learning, but also self- and collective teacher efficacy. Self-regulation in language learning is connected to the learners taking responsibility for their own learning (Oxford, 2017). Teacher self-efficacy refers to the beliefs teachers hold about their capability to influence student learning (Klassen $\&$ Chiu, 2010) and collective teacher efficacy (CTE) is the collective belief of teachers in their ability to positively affect students (Hattie, 2015). CTE is associated with a number of productive behaviors including implementation of school improvement strategies, increased teacher leadership, communication of high expectations, and a strong focus on academic pursuits (Donohoo, 2018). We therefore place language learning strategies and language strategy instruction in the broader field of metacognitive behavior in school settings.

We understand LLS as an expression of metacognition and self-regulated learning, and offer here both a broad theoretical overview of research on metacognition in CLIL worldwide, and two more focused comparing and contrasting views of strategizing learning in CLIL practice - one from the viewpoint of teachers in Australia, and the other from research into students learning in classrooms in the Basque Country.

The experiences of teachers and learners in the 21st century mainstream classrooms are characterized by ubiquitous standardized testing regimes. CLIL programs are not exempt of these pressures, but they explore integrative and transformative repertoires of teaching and learning that 
require a re-conceptualization of knowledge construction, meaning-making, creativity and ownership (Fullan \& Langworthy, 2014) by allowing students to engage with content through the prism of two languages. We understand the development of metacognitive awareness (both for teachers and learners) as an integral part of such knowledge construction in a learning situation that is utilizing two (or more) languages.

\section{Metacognitive Awareness, Self-regulated Learning and Language Learning Strategies in CLIL}

This section introduces our conceptual framework based on metacognitive awareness in teachers and students. We understand metacognition and metacognitive awareness as an integral component of language learning strategies and strategy instruction, the two interrelated aspects we are interested in here. Metacognition is "the ability to reflect upon, understand and control one's learning" (Schraw \& Dennison, 1994, p. 460). In our understanding of metacognitive awareness, we follow Bialystok's (1993) approach:

The term 'metacognition' has been used in the psychological literature to refer to both 'knowledge about cognition and regulation of cognition'; rather than signaling a contradiction, it may be that these two functions may reflect two different but equally essential components of the processing that determine the difference between cognition and metacognition. The first of these is the requirement for specific types of knowledge structures and the properties entailed by them; the second is the requirement for a degree of intentionality in cognitive processing, the possibility that these are two functionally distinct but equally important aspects of metacognitive processing is the basis for the discussion of metalinguistic awareness [in children] (...). (p. 211)

Metacognitive awareness, in this view, can refer to executive control of language functions, such as grammaticality judgment (Bialystok et al., 2014), as well as the readiness of using metacognitive strategies such as directing attention and mental translation (Rahimi \& Katal, 2012, quoted in Zhou \& Wei, 2018). Metacognition is often connected to Jean Piaget's (1929) notion of intentionality, which presupposes thinking that is deliberate and goaldirected and involves planning a sequence of actions. While research in the field of languages has extensively focused on the differences between metalinguistic awareness in bilingual and monolingual children (see cf. Bialystock \& Barac, 2012), we focus here on an exploration of intentionality as part of student's metacognition about LLS use, and teacher's intentions to instruct students in using strategies. Intentionality as regulation of cognition in language learning was explored in the debates on the role of consciousness in second language learning, and learning in general, some 20 years ago (see cf. Hulstijn \& Schmidt, 1994).

The importance of metacognition in teaching and learning has been pointed out by several CLIL researchers. Mehisto (2013) suggests that " (...) if teachers do not raise their metacognitive and meta-affective awareness through discussion, they will be less likely to consciously manage their beliefs and the impact of those beliefs on students and a school's ethos" (p. 33). Fortanet-Gómez (2010, as quoted in Costa, 2013, p. 119) "also thinks that these teachers must be made aware of the fact that it is not enough to translate their lesson into another tongue; they must also focus on both the language and content. According to FortanetGómez (ibid., p. 119), "a training course for such professors must be set up and start from a self-reflection on the didactical approach. CLIL teachers must be trained with regard to aspects that are usually dealt with in language courses, such as metacognitive skills, assessment (which must be a joint evaluation), the use of code-switching, vocabulary, oral presentations, etc."

These voices point to aspects of strategy instruction highlighted by Plonsky (2011) in his systematic review of strategy instruction research. Plonsky summarizes definitions of strategy instruction as "explicit instruction on specific practices or techniques that can be employed autonomously to improve one's L2 learning and/or use", citing Cohen's (1998) statement that strategies-based instruction ultimately aims to "empower students by allowing them to take control of the language learning process" (Cohen, 1998, p. 70, cited in Plonsky, 2011). Plonsky identifies strategy instructions as highly context dependent, with aspects such as the proficiency level of students, the nature of language learning (second, foreign), the approach to strategy instruction (timing, length, 
repetition, level of embeddedness, opportunities for scaffolding and guided practice), metacognitive awareness raising and evaluation of practices central to the implementation in classrooms.

Hawker (2013, p. 159) asserts that "over the past decade, a rapidly increasing body of literature has provided fairly strong support, both theoretically and empirically, for the idea that learning under the CLIL approach is a cognitively enriched experience which has the potential to sustain thinking of a higher order and boost metacognitive awareness (Coyle et al., 2010; Lorenzo et al., 2010; Jäppinen, 2005; Stohler, 2006; Ting 2011; Vollmer, 2008; Zydatiß, 2007)". More specifically, Hansen-Pauly (2013) links metacognitive awareness to one of the key pedagogical frameworks in CLIL, the 4Cs model (communication, cognition, content and culture) by Do Coyle (2007). Hansen-Pauly (2013) points out that "for all the principles that underpin Coyle's framework the idea of a constructivist and interactive approach is fundamental (Coyle, 2007, p. 550)", and that for Coyle, "cognitive and metacognitive processes enhance the link between content and linguistic demands" (Hansen-Pauly, 2013, p. 226). However, she also reminds us that “(...) most students appear more interested in topical issues than in metacognitive and learning skills, including reflection on language use" (Hansen-Pauly, 2013, p. 232), and indicates that there some gaps in the research:

Though the dominant pedagogical discourse emphasises learner autonomy and metacognitive skills, few attempts have been made to raise the learners' (and teachers') own awareness of this interdependence of language and thought. Learning in a second or foreign language supposedly requires more effort and possibly yields more frustration than learning in a first language - so learning situations must be truly meaningful and empowering for learners to assume their responsibility and overcome obstacles. (p. 235)

The failure to understand and focus on self-regulated learning skills and metacognitive awareness in CLIL can have serious consequences. Mehisto (2013) gives an insight into research findings that confirm the importance of planning, monitoring and evaluating learning, the three key steps of self-regulation. She/he is worth quoting at length on this point:
The consequence of not helping students to develop learning skills, to become more autonomous and self-motivated learners can leave those students who are least prepared to manage their own learning at a distinct and likely ever-growing disadvantage. For example, Watkins (2005, p. 80, referring to Atkinson, 1999) reports on a study that reviewed General Certificate of Secondary Education (GCSE) examination results in England and found that students who "plan the least have just $30 \%$ of the scores of pupils who plan the most". In situations where students are faced with intellectually challenging tasks, Veenman et al. (2002, p. 337), who studied over 300 first-year university students, found that meta-cognitive skills are a greater determinant of student achievement than intellectual ability as measured by IQ tests. This suggests that building learning skills for the learning of content and language has an important role to play in CLIL. Similarly, Chamot (2005), Knouzi et al. (2010), Edmondson (2009) and Kohonen (2009) all argue that effective language learners operate with a high degree of learner autonomy meaning that they are skilled at managing their own learning. (p. 30)

Empirical studies underpin Hawker's (2013) assertion that CLIL environments seem to strengthen the need to develop metacognitive awareness. Nieto Moreno de Diezmas (2016) reports on a study that involved 1,966 students in bilingual CLIL programs and 14,713 students in mainstream classes in the Spanish region of Castilla-La Mancha enrolled in the 2nd year of Compulsory Secondary Education. Students took a series of tests designed to assess metacognitive strategies and learning strategies. The results of the study showed that students in bilingual CLIL programs scored significantly higher than the control group on the key competence of learning to learn:

CLIL students significantly outperformed their peers in both learning to learn dimensions, "metacognitive strategies" and "learning and selfregulation strategies". They also displayed significantly higher scores for all standards tested: "identification of own learning styles", "selfevaluation of results", "organisation of information in conceptual maps", "integration of information in 
content sheets", "outlining the main ideas", "planning a written text" and "presenting clear and logically ordered texts." The data analysed lead us to conclude that CLIL methodology has a positive effect on the development of learning to learn strategies. (p. 30)

It is therefore not surprising that a more transparent engagement with the cognitive processes involved in the construction of knowledge in CLIL has lately become the focus of research. Reitbauer et al. (2018) claims that raising teachers' awareness of the epistemic function of language and drawing their attention to the human cognitive architecture can help them achieve a higher level of understanding of the process of integration of content and language" (p. 88). Based on a study of a task design taken from a training course for CLIL teachers in Austria, the authors conclude, "language is central to the process of knowledge construction (epistemic function of language), and awareness of cognitive discourse functions are at the interface of thinking and language" (p. 103). Such calls for metacognitive awareness resonate with cognitive load theory (Sweller, 1988), which requires that in content-based instruction programs like CLIL programs, "students need both the prerequisite content background knowledge as well as sufficient language ability in order for their cognitive resources to be focused on the learning objective of the class" (Graham et al., 2018, p. 22). We argue here that strategy instruction in self-regulated metacognitive learning strategies like goal-setting and checking progress can support metacognitive awareness of language functions and learning objectives, as proposed in a study by Lozano Velandia (2015):

Self-set goals and reflection helped learners focus on the specific language functions and vocabulary necessary to complete communicative tasks (roleplays) successfully, and that this led to increased learner awareness, confidence, and positive selfconcept. In addition, learners showed progress in development of specific (e.g., English for Specific Purposes) language functions and technical vocabulary. (p. 131)

Strategy instruction in content-based language learning contexts is under-researched; for example, Plonsky (2011) does not mention a single example of research in CLIL, bilingual or immersion contexts in his systematic review. It is therefore worth taking a look at what has been researched about the role of learners and teachers in CLIL, and how further research on strategy instruction can build up on existing insights.

\section{Teachers in the CLIL Classroom}

There is still limited research into strategy instruction and language learning strategy use of teachers and learners in CLIL settings. Much of the research that has been conducted up to now has been product-oriented research (Dalton Puffer et al., 2010; Juan-Garau \& Salazar-Noguera, 2015; Ruiz de Zarobe \& Jiménez Catalán, 2009; Ruiz de Zarobe et al., 2011), i.e., research that has investigated if CLIL can produce better results than more traditional educational contexts mainly in terms of language outcomes. However, in order to test the importance of the approach, it is necessary to analyze what is taking place in the CLIL classroom, constituting a more process-oriented focus in all its variety (Nikula et al., 2016). One of the questions that needs to be addressed is how we can use the CLIL classroom as the appropriate context to move towards independent language learning strategy use while enhancing successful content learning (Coyle, 2013), and integration, a major aim of the approach itself (Ruiz de Zarobe \& Cenoz, 2015).

Quite interestingly, CLIL pedagogy has often been associated with "good teaching", with "innovative, studentcentred pedagogical approaches" (van Kampen et al., 2018, pp. 223-224). Yet, little is still known of what actually takes place in the CLIL classroom and, what is more important, which instructional pedagogies can be most efficient in CLIL. What has been published on CLIL classroom research across many different educational contexts has quite frequently focused on the teacher. For instance, Van Kampen et al. (2018) analyzed CLIL pedagogies used by teachers in the Netherlands using self-reported survey data and interviews. Their results showed that CLIL teachers considered CLIL as a unique pedagogy in that it integrates content and language teaching. They further argued that CLIL teaching is more interactive and focuses more on higher level cognitive skills. However, there were some concerns about focus on form in this study. Teachers' focus on language was very limited in their classroom: they stimulated spoken output but hardly ever were language 
forms corrected. This has been corroborated by other studies on the field. Thus, De Graaff et al. (2007) through observation of CLIL lessons from three Dutch CLIL secondary schools found how the didactic innovation inherent in CLIL gives teachers an opportunity to break down the barriers and to collaborate in a new learning and teaching environment, facilitating exposure to input and output production and using compensation strategies when necessary. Similarly to what Kampen et al. (2018) argued, teachers in their study used innovative teaching tools, but they seldom facilitated and corrected learners' use of English. That has also been found in other contexts such as Spain (Morton, 2010) or Sweden (Airey, 2012).

The change of classroom pedagogy, from a more teacher-centered approach, typical of traditional teaching contexts, to a more student-centered approach, has often been addressed in CLIL classrooms in relation to the role of the teacher and the student. In Finland, Nikula (2010) compared a biology teacher's instructional style in CLIL and non-CLIL lessons, as well as teacher-student interaction. She found that the students adopted a more active role in the CLIL classes, compared to more traditional ones, and that they found themselves "on a more equal footing with the teacher as far as the right to participate in classroom discourse is concerned" (Nikula, 2010, p. 119). Furthermore, teachers used less varied language, mainly in cases where they felt they had a limited competence in the foreign language. Different results were presented in other studies, such as Mahan et al. (2018, p. 13) in the Norwegian context, where teachers' instruction in CLIL lessons was found to be "rich, lengthy and accurate".

Even though it is interesting and necessary to study if CLIL settings may involve a change in classroom pedagogy, our aim in this paper is to go one step further by focusing on the students' active role in strategy use and the teacher's role in strategy instruction. As Koopeman et al. (2014, p. 124) state with regard to research in the Dutch context, "most of the studies have focused mainly on learner outcomes and results rather than pedagogy; those that have looked at pedagogy have done so from a 'process-product' perspective." This idea is also present in Van Kampen et al. (2018, p. 225), where "the few studies investigating pedagogy have tended to do so from a 'process-product' perspective, with teacher behavior (process) used to predict learner outcomes (product)". However, it is our opinion that when learners actively participate in the process, when they actively understand how and under which conditions they can learn, deeper understanding of learning takes place. This involves learner-based research with different levels of control and involvement on the part of the children (Anderson, 1999). This is precisely what we have aimed to do in the research conducted in a multilingual context in the Basque Country, which involves CLIL, learning strategies and metacognitive awareness, as the following section will present.

\section{Metacognition, learning strategies and CLIL in the Basque Country}

Metacognitive awareness refers to the knowledge that learners have of the learning process, the readiness they have to use metacognitive strategies, and how they can develop skills and processes that support their learning (Zhang, 2010). Even though the notions of metacognitive strategies and metacognition have quite often been used interchangeably (Goh, 2019), our objective here is to see how metacognitive awareness can be used in learning and teaching in CLIL settings. Our aim in this study is to see how metacognition can be fostered through instruction in the case of learning strategies. More precisely, our study analyses metacognitive awareness in reading and includes knowledge of the strategies that students use or should use while reading, the strategies involved in planning, monitoring and evaluating the reading process.

Taking into consideration the importance of metacognitive awareness, our study made use of some strategic interventions (Carrell, 1998) to raise learners' awareness. This study involved a pre- and post-test design in Year 5 and Year 6 classes (age 11-13) at a school in the Basque Country in Spain. In the school, there was a balanced use of the three languages (Spanish, the majority language, Basque, the minority language, and English, the foreign language). English, physical education, arts and crafts, and science were taught through English; Basque, music, religion and tutorials were carried out in Basque, and all other subjects (Spanish and mathematics) were undertaken in Spanish. This school was part of what was called the Trilingual Education Framework (see Ruiz de Zarobe, 2015), with several subjects conducted in the foreign language through CLIL, apart from the two official 
languages of the community (Spanish and Basque). In our research there were four intact groups of learners with 100 students, two groups of learners $(N=50)$ were divided into control $(\mathrm{CG})$ and two $(N=50)$ into experimental groups (EG). The EG received instruction on reading strategies based on broad skills, using Chamot's (2001) taxonomy. Some of the skills focused on in Year 5 included: 'activate background knowledge', 'make predictions', 'guess from context', 'observe the layout of the text' and 'pay attention to the type of text'. In Year 6 we included skills such as: 'identify the main ideas', 'tell fact from opinion', 'discover the author's intentions' and 'tell true from false'.

Strategies that focused on achieving these skills were explicitly taught by the teacher/researcher to the EG over a seven-week period, providing examples of when, for what tasks and how they could be used effectively to increase reading comprehension. Each strategy was associated with an icon (see Figure 1) to be remembered and retrieved more easily by the learners.

Figure 1. 'Activate Previous Knowledge' Icon

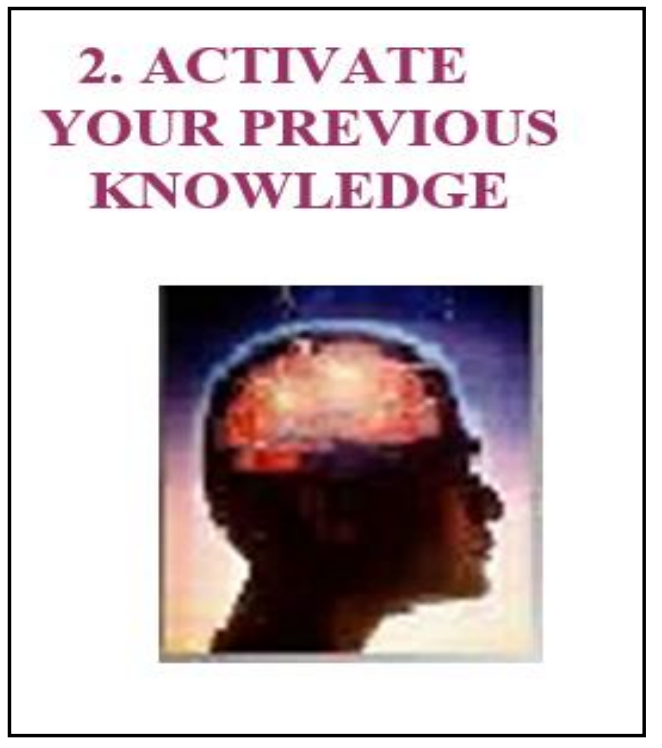

We followed the Cognitive Academic Language Learning Approach (CALLA) developed by O'Malley and Chamot (1990), a model that is amply used today for LLSI (see, for instance, Chamot \& Harris, 2019, where many of the chapters follow this format). It basically follows five different phases: preparation/awareness raising, presentation/modelling, practice, evaluation and expansion/transfer, which allow for both content and language learning. As Chamot and Harris (2019) state in the introduction to their book, "the overall aim is gradually to shift responsibility from the teacher to the learner" (p. xxvi), and that was also our intention here.

Figure 2 shows one of the texts used for the strategy "activate previous knowledge". Most texts were taken from science, as this was one of the subjects conducted in English. After reading the text, students had to complete a multiplechoice test, with questions such as those in Figure 3.

Apart from the multiple-choice tests, learners were asked to answer some specific questions related to the strategy under review. These are shown in Figure 4.

After the strategies were presented and practiced, the students completed a diary in every session to gather qualitative information about the difficulty and usefulness of the strategy. These diaries were useful for instructional purposes to help students reflect on the learning processes and the strategies while also developing metacognitive awareness (Rubin, 2003). Quite often strategy knowledge was defined by the students themselves, enumerating the strategies they had used and how effectively they appeared to use them to improve the reading process (Sheorey \& Mokhtari, 2001).

Our results (see Ruiz de Zarobe \& Zenotz, 2015; Ruiz de Zarobe \& Zenotz, 2018 for a thorough explanation of the intervention and its effects over time) showed how students who were thus instructed in reading strategies seemed to have greater metacognitive awareness, and were also more cognitively engaged in the CLIL classroom, e.g., by applying these strategies regularly. Strategy instruction supported self-control mechanisms, helping students become more aware of the reading process and, eventually more strategic readers. Furthermore, we also found that if students actively take part in the learning process, they can eventually become more independent learners, capable of controlling their own learning with the linguistic repertoires they possess, which is desirable in multilingual education (Cenoz \& Gorter, 2015). 
Figure 2. Frogs

\section{FROGS}

\section{What are frogs?}

Frogs are amphibians that live on land and in water. Frogs have long back legs and short bodies. Their eyes stick out. They do not have tails. Most of the time they move in the water, but they can also move on land. Frogs have smooth, not bumpy, skin.

How do they breathe and move?

They can breathe through their skin. Their skin must stay wet so they can breathe through it. Young frogs must breathe through their skin. Older frogs grow lungs. They breathe through their lungs when they are on land, just like people do. Frogs lay eggs in ponds and other bodies of water, like lakes. Frogs must move fast to catch something to eat. They must also get away from bigger animals. Some frogs have webs of skin between their toes. So, they can swim fast. Tree frogs have toe pads. The toe pads help them hang on when they climb. When they climb, they move up trees or rocks. Some tree frogs live high in very tall trees. Those tree frogs have webs between their toes. They can jump from tree to tree. They can't fly, but they can stay in the air for a long jump.

What do they eat?

Amphibians like frogs change their eating habits as they grow old. Tadpoles are herbivores and eat aquatic plants. Adults are carnivores. They eat insects and snails, and sometimes some small vertebrates.

Figure 3. Frogs: Multiple-choice Test Sample
1. A young frog's skin must be wet so
2. Some frogs have toe pads to help them
a. the frog can swim.
a. climb.
b. the frog can climb.
b. swim.
c. the frog can lay eggs.
c. jump.
d. the frog can breathe.
d. fly.

Figure 4. Frogs: Activate Your Previous Knowledge

\section{ACTIVATING YOUR PREVIOUS KNOWLEDGE}

1. Could you have answered any of the questions without reading the text? Which ones?

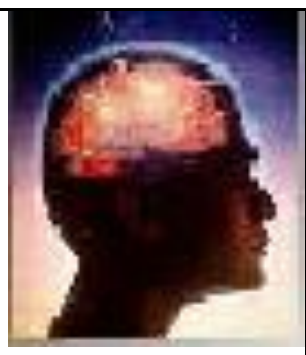

2. When have you heard about this topic before? In class?

3. Has thinking and talking about frogs helped you understand the text? Why? 


\section{Teachers Reflecting on CLIL Programs}

We claim in this article that there might be an intersection between these learning processes experienced by students in CLIL programs, and the sense of efficacy teachers experience when using explicit strategy instruction. We define teacher efficacy here as the teacher's sense of confidence that they will teach successfully in a particular context. We establish the link to metacognitive awareness by examining the role of teacher reflection and teacher decision-making in a selection of CLIL programs. We define metacognitive awareness in teachers as self-reported reflections of underlying pedagogy of instructional plans and self-efficacy toward instructional planning (Baylor, 2002).

The study we revisit for this perspective, our second study presented here, is based in Australia, where CLIL programs in a variety of languages have established a small niche within the wider schooling landscape. Based on a qualitative study of interviews with CLIL program directors and teachers (T1- T12, to de-identify the quotes) across 12 CLIL programs in six different languages in the state of Queensland, we provide here an insight into the metacognitive awareness of teachers in CLIL programs. For the purposes of this article, we are focusing on one research question: What role does strategy instruction have in the integration of content and language in the CLIL classroom? For a more detailed overview of the base study, several articles provide analyses of the unique experiences of teachers when two (or more) languages are used as a medium of instruction (Smala, 2013, 2014, 2016).

In a summary analysis, interviewees in this study instructed their students in the following language learning strategies that integrate the content and language focus:

1. Select to learn vocabulary specific for the lesson topic - this might mean that the vocabulary is distinct from the vocabulary learnt during accompanying language lesson, and might differ in sequence (past tense forms need to be learnt before they are covered in the language classroom, for example)

2. Practice your understanding of classroom commands and how to respond to them - the focus is the content, and content message and understanding is more important than errors in language forms

3. Use a dictionary, not an online translator. Avoid translating whole paragraphs through an online translator.

4. Look up concepts in your native language if you feel you need a deeper understanding. A bit of translanguaging is generally encouraged to support content message and understanding.

5. Look for familiar words or cognates that you already know from previous studies of the lesson topic in your native language (for example, prior knowledge of science words that look familiar in the second language medium).

6. Organize your vocabulary learning for a particular topic into "necessary", "indispensable" and "essential", and learn the meanings for all these terms as key components of the content. (These will be added purposefully to all texts for recognition).

7. Focus on the vocabulary that helps you do the assessment tasks, for example 'compare and contrast two planets'- learn the vocabulary and language structures needed to compare and contrast (teacher provides these).

8. List patterns in language structures that you notice and reproduce these in your own work about a specific lesson topic.

9. Use familiar language learning strategies like post-it notes in your room, mobile apps and online flashcard creators.

For many teachers, working in a CLIL program represents unprecedented levels of metalinguistic and metacognitive awareness, including linguistic communicative competence, micro-linguistic competence, and linguistic flexibility (Bier, 2016). In Bier's (2016) words, "CLIL teachers need to master an array of strategies in order to facilitate students' comprehension (scaffolding strategies); to encourage student deep reflection upon content and oral production of what has been understood; to 
assess students' comprehension" (p. 398). The nine strategies above, summarized from the interview data, indicate that teachers' scaffolding strategy instruction draws upon those language use strategies that they themselves have at their disposal when simplifying materials for CLIL lessons (a key teaching approach reported by all interviewees), and which they are now sharing with their students.

Target language competences have been identified as part of the key skill set for CLIL teachers (Bertaux et al., 2009), and previous studies have linked perceived proficiency levels for example to language teacher efficacy (Chacon, 2005; Moate, 2011; Turner, 2018). Instructing CLIL students in reading strategies and self-regulated learning, as examined in the first study used in our article, requires teachers to develop knowledge of language learning strategies as well as strategy instruction to support the learning of linguistic and content structures required for specific lesson topics.

However, the interview data revealed ambiguous perspectives towards the importance assigned to native language proficiency in this endeavor. In general, most interviewees felt that the presence of native speaker teachers enhanced their sense of collective efficacy in selecting language structures. However, when reflecting on strategy instruction practices, interviewees own experiences as second language learners were seen as beneficial in understanding language learning strategies, and how to instruct students to use them. Interestingly, "native proficiency" was occasionally singled out as difficult to integrate in the CLIL learning processes:

So inviting, as I had done, a fellow who is an excellent musician, he's of [language dialect variety] background and I invited him a couple of times in the classroom to talk about various things. Now, he found it difficult to sustain what was happening in the classroom in [standard variety], to sustain what he was talking about through his [language dialect variety]. So he did a lot of code switching and he did a lot of what they call using Austral[language dialect variety], this sort of combination of the dialect mixed with English. I just didn't think it fulfilled the sort of requirements that I wanted in an immersion program where we are trying to use... and I think we do use what they call "standard [language variety]" which is sort of stuff that teachers are using in [the target language country].

The teacher invited a native speaker of the target language into the classroom, who was in fact a speaker of a native dialect of the target language. The quote exposes pedagogical reflections and decisions, from the initial choice to invite a native speaker with cultural knowledge (the musical connection), to the realization that the linguistic skills of the visitor in the standard variety of the target language were too limited for the language structures and vocabulary choices required for content message and understanding of the subject topic. The teacher's (T2) statement, "he found it difficult to sustain what was happening in the classroom," hints at the conflicting considerations this teacher had around teaching approaches, language learning strategies, and strategy instruction. Inviting a native speaker was a desirable social engagement for students, but this intercultural experience clashed with the more pressing needs to focus on content message and understanding through targeted and focused language learning of key vocabulary.

In summary, strategy instruction in CLIL classrooms seems to be driven by the specific needs of lesson topics and is making use of familiar language learning strategies such as memory strategies for vocabulary learning. However, there are also CLIL specific strategies that activate the metacognitive awareness of students about potentially conflicting language needs in their accompanying language classes and the subject-specific vocabulary and language structures (past tense for classroom genres like reports etc.) in their CLIL lessons. Teachers in CLIL programs seem to experience a shift away from language-teaching specific methods like the inclusion of intercultural information and social language learning strategies that focus on intercultural communication, towards more content-focused strategy instructions that allows students to cope with the learning processes in subjects like science and math.

\section{CONCLUSION}

Further research is needed to explore sustained language learning strategy instruction for the purposes of CLIL and other bilingual classroom settings. One area we have 
identified for further exploration is the intersection of metacognitive awareness of teachers and students in CLIL classrooms. We approached metacognitive awareness from two positions: 1) as a concept that describes self-regulated learning in students and constitutes one of the important areas of language learning strategies (metacognitive strategies), and 2) as a key concept when describing the decisions teachers make in their pedagogical planning and implementation, including when deciding on which language learning strategies to single out for instruction, and how to instruct these. The first position conceptualizes students as active agents in CLIL classrooms and acknowledges the role language learning strategies such as reading strategies in a second language have for students' coping strategies and self-regulated learning in CLIL settings. The second locates metacognition in the reflections and decisions CLIL teachers make about the demands of the
CLIL classroom. We understand these two positions as interrelated and "speaking to each other", scaffolding the learning processes through focused attention to vocabulary and language structures needed for content message and understanding. While metacognition has been the object of numerous investigations into student learning in CLIL, research into teachers' metacognitive awareness in CLIL and other bilingual settings still is in its infancy. For future research, we propose a focus on CLIL teachers reflective cycles that take into account students' prior knowledge (e.g., cognates, language learning strategies learnt in mainstream language classes, understanding of subject-specific concepts in native language), to build up a repertoire of language learning strategies and strategy instruction that supports the processes when integrating language and content learning.

\section{Acknowledgments}

We would like to acknowledge the funding awarded by the Spanish Ministry of Economy and Competitiveness MINECO [grant number FFI2012-31811], MINECO/FEDER [grant number FFI2015-63715-P] and the Basque Department of Education, Research and Universities IT311-10 (UFI 11/06).

\section{Notes on the authors}

Yolanda Ruiz de Zarobe is Full Professor in Applied Linguistics at the University of the Basque Country, Spain. Her research interests focus on the acquisition of English as a second and third language, multilingualism and Content and Language Integrated Learning (CLIL).

Simone Smala is a Senior Lecturer in the School of Education, the University of Queensland, Australia. Her research fields include Educational Psychology, Learning Theories, CLIL, metacognition, and teacher agency.

\section{REFERENCES}

Airey, J. (2012). I don't teach language: the linguistic attitudes of physics lecturers in Sweden. AILA Review, 25(1), 64-79. https://doi.org/10.1075/aila.25.05air

Anderson, N. J. (1999). Exploring second language reading: Issues and strategies. Heinle \& Heinle. https://doi.org/10.2307/3588105

Atkinson, E. S. (1999). Key factors influencing pupil motivation in design and technology. Journal of Technology Education, 10(2), 4-26. https://doi.org/10.21061/jte.v10i2.a.1
Banegas, D. L. (2011). Content and language integrated learning in Argentina 2008-2011. Latin American Journal of Content \& Language Integrated Learning, 4(2), 33-50. https://doi.org/10.5294/lacli1.2011.4.2.4

Baylor, A. (2002). Expanding preservice teachers' metacognitive awareness of instructional planning through pedagogical agents. Educational Technology Research and Development, 50(2), 522. https://doi.org/10.1007/BF02504991

Bertaux, P., Coonan, C. M., Frigols-Martín, M. J., \& Mehisto, P. (2009). The CLIL teacher's competences grid. Common Constitution and 
Language Learning (CCLL) Comenius Network. http://tplusm.net/CLIL_Competences_Grid_31.12. 09.pdf

Bialystok, E. (1993). Metalinguistic awareness: The development of children's representations of language. In C. Pratt \& A. F. Garton (Eds.), Systems of representation in children: Development and use. (pp. 211-233). Wiley. https://doi.org/10.1007/978-3-642-69113-3 8

Bialystok, E., \& Barac, R. (2012). Emerging bilingualism: Dissociating advantages for metalinguistic awareness and executive control. Cognition, 122(1), 67-73. https://doi.org/10.1016/j.cognition.2011.08.003

Bialystok, E., Peets, K. F., \& Moreno, S. (2014). Producing bilinguals through immersion education: Development of metalinguistic awareness. Applied Psycholinguist, 35(1), 177191. https://doi.org/10.1017/S0142716412000288

Bier, A. (2016). An Inquiry into the methodological awareness of experienced and less-experienced Italian CLIL teachers. Educazione Linguistica Language Education, 5(3), 395-414. http://doi.org/10.14277/2280-6792/ELLE-5-3-4

Carrell, P. L. (1998). Can reading strategies be successfully taught? Australian Review of Applied Linguistics, 21(1), 1-20. https://doi.org/10.1075/aral.21.1.01car

Cenoz, J., \& Gorter, D. (2015). Multilingual education: Between language learning and translanguaging. Cambridge University Press. https://doi.org/10.1007/978-3-319-94851-5_12

Chacón, C. T. (2005). Teachers' perceived efficacy among English as a foreign language teacher in middle schools in Venezuela. Teaching and Teacher Education, 21, 257-272. https://doi.org/10.1016/j.tate.2005.01.001

Chamot, A. U. (2001). Teaching learning strategies in immersion classrooms: The elementary immersion learning strategies resource guide. http://carla.umn.edu/immersion/acie/vol5/Nov200 1.pdf
Chamot, A. U. (2005). Language learning strategy instruction: Current issues and research. Annual Review of Applied Linguistics, 25, 112-130. https://doi.org/10.1017/S0267190505000061

Chamot, A. U., \& Harris, V. (2019). Learning strategy instruction in the language classroom: Issues and interpretation. Multilingual Matters. https://doi.org/10.21832/CHAMOT3408

Cohen, A. D. (1998). Strategies in learning and using a second language. Longman. https://doi.org/10.4324/9781315833200

Cohen, A. D., \& Wang, I. K.-H. (2018). Fluctuation in the functions of language learner strategies. System, 74, 169-182. https://doi.org/10.1016/j.system.2018.03.011

Costa, F. (2013). "Dealing with the language aspect? Personally, no." Content lecturers' views in an ICLHE context. In S. Breidbach \& B. Viebrock (Eds.), Content and language integrated learning (CLIL) in Europe: Research perspectives on policy and practice (pp. 221-238). Peter Lang. https://doi.org/10.3726/978-3-653-02955-0

Coyle, D. (2007). Content and language integrated learning: Towards a connected research agenda for CLIL pedagogies. International Journal of Bilingual Education and Bilingualism, 10(5), 543562. https://doi.org/10.2167/beb459.0

Coyle, D. (2013). Listening to learners: An investigation into 'successful learning' across CLIL contexts. International Journal of Bilingual Education and Bilingualism, 16(3), 244-266. https://doi.org/10.1080/13670050.2013.777384

Coyle, D., Hood, P., \& Marsh, D. (2010). Content and language integrated learning. Cambridge University Press.

Dalton-Puffer, C., Nikula, T., \& Smit, U. (2010). Language use and language learning in CLIL classrooms. John Benjamins. https://doi.org/10.1075/aals.7.14dal

De Graaff, R., Koopman, G. J., Anikina, Y., \& Westhoff, G. (2007). An observation tool for effective L2 pedagogy in content and language integrated 
learning (CLIL). International Journal of

Bilingual Education and Bilingualism, 10(5), 603-

624. https://doi.org/10.2167/beb462.0

Donohoo, J. (2018). Collective teacher efficacy research:

Productive patterns of behaviour and other positive consequences. Journal of Educational

Change, 19(3), 323-345.

https://doi.org/10.1007/s10833-018-9319-2

Edmondson, W. (2009). Language awareness. In K. Knapp, B. Seidelhofer, \& H. Widdowson (Eds.), Handbook of foreign language communication and learning (pp. 163-190). Mouton de Gruyter.

Fortanet-Gómez, I. (2010). Training CLIL teachers for the university. In D. Lasagabaster \& Y. Ruiz de Zarobe (Eds.), CLIL in Spain: Implementation, results and teacher training (pp. 257-276).

Cambridge Scholars Publishing.

https://doi.org/10.1093/elt/ccr056

Fullan, M., \& Langworthy, M. (2014). A rich seam: How new pedagogies find deep learning. Pearson. https://doi.org/10.1080/15700763.2015.1073331

Goh, C. (2019). What we still need to learn about language learning strategies instruction: Research directions and designs. In A. U. Chamot \& V. Harris (Eds.), Learning strategy instruction in the language classroom: Issues and interpretation (pp. 262278). Multilingual Matters. https://doi.org/10.21832/9781788923415-026

Graham, K. M., Choi, Y., Davoodi, A., Razmeh, S., \& Dixon, L. Q. (2018). Language and content outcomes of CLIL and EMI: A systematic review. Latin American Journal for Content \& Language Integrated Learning, 11(1), 19-37. https://doi.org/10.5294/lacli1.2018.11.1.2

Hansen-Pauly, M.-A. (2013). CLIL as a new momentum for learning? Reconsidering the differences between languages as subjects and vehicular languages in Luxembourg Schools. In S. Breidbach \& B. Viebrock (Eds.), Content and language integrated learning (CLIL) in Europe: Research perspectives on policy and practice (pp. 117-127). Peter Lang. https://doi.org/10.3726/978-3-653-02955-0
Hattie, J. (2015). The applicability of visible learning to higher education. Scholarship of Teaching and Learning in Psychology, 1(1), 79-91. https://doi.org/10.1037/st10000021

Hawker, I. A. (2013). The CLIL learning experience: Strategies and underlying knowledge employed by limited English primary school students during conceptual and linguistic comprehension. In S. Breidbach \& B. Viebrock, (Eds.), Content and language integrated learning (CLIL) in Europe: Research perspectives on policy and practice (pp. 159-179). Peter Lang.

Hulstijn, J. H., \& Schmidt, R. (1994). Consciousness in second language learning. AILA Review, 11, 1128.

Jäppinen, A.-K. (2005). Thinking and content learning of mathematics and science as cognitional development in content and language integrated learning (CLIL): Teaching through a foreign language in Finland. Language and Education, 19, 148-169. https://doi.org/10.1080/09500780508668671

Juan-Garau, M., \& Salazar-Noguera, J. (2015). Contentbased language learning in multilingual educational environments. Springer. https://doi.org/10.1007/978-3-319-11496-5

Klassen, R. M., \& Chiu, M. M. (2010). Effects on teachers' self-efficacy and job satisfaction: Teacher gender, years of experience, and job stress. Journal of Educational Psychology, 102(3), 741-756. https://doi.org/10.1037/a0019237

Knouzi, I., Swain, M., Lapkin, S., \& Brooks, L. (2010). Self-scaffolding mediated by languaging: Microgenetic analysis of high and low performers. International Journal of Applied Linguistics, 20(1), 23-49. https://doi.org/10.1111/j.14734192.2009.00227.x.

Koopman, G. J., Skeet, J., \& de Graaff, R. (2014). Exploring content teachers' knowledge of language pedagogy: A report on a small-scale research project in a Dutch CLIL context. The Language Learning Journal, 42(2), 123-136. https://doi.org/10.1080/09571736.2014.889974 
Lin, A. M. Y. (2016). Language across the curriculum \& CLIL in English as an additional language (EAL) contexts: Theory and practice. Springer. https://doi.org/10.1007/978-981-10-1802-2

Lorenzo, F., Casal, S., \& Moore, P. (2010). The effects of content and language integrated learning in European education: Key findings from the Andalusian sections evaluation project. Applied Linguistics, 31, 418-42. https://doi.org/10.1093/applin/amp041

Lozano Velandia, S. A. (2015). Goal setting and selfreflection to enhance learners' interaction in an ESP context. Latin American Journal of Content and Language Integrated Learning, 8(2), 131160. https://doi.org/10.5294/lacli1.2015.8.2.4

Mahan, K. R., Brevik, L. M., \& Ødegaard, M. (2018). Characterizing CLIL teaching: New insights from a lower secondary classroom. International Journal of Bilingual Education and Bilingualism, $1-18$.

https://doi.org/10.1080/13670050.2018.1472206

Mehisto, P. (2013). Integrating CLIL with other mainstream discourses in content and language integrated learning (CLIL). In S. Breidbach \& B. Viebrock (Eds.), Content and language integrated learning (CLIL) in Europe: Research perspectives on policy and practice (pp. 25-50). Peter Lang.

Moate, J. (2011). The impact of foreign language mediated teaching on teachers' sense of professional integrity in the CLIL classroom. European Journal of Teacher Education, 34(3), 333-346. https://doi.org/10.1080/02619768.2011.585023

Morton, T. (2010). Using a genre-based approach to integrating content and language in CLIL. In C. Dalton-Puffer, T. Nikula, \& U. Smit. (Eds.), Language use and language learning in CLIL classrooms (pp. 81-104). John Benjamins. https://doi.org/10.1075/aals.7.05mor

Nieto Moreno de Diezmas, E. (2016). The impact of CLIL on the acquisition of the learning to learn competence in secondary school education in the bilingual programmes of Castilla-La Mancha.
Porta Linguarum, 25, 21-34.

https://doi.org/10.6018/ijes/2016/2/239611

Nikula, T. (2010). Effects of CLIL on a teacher's language use. In C. Dalton-Puffer, T. Nikula, \& U. Smit (Eds.), Language use and language learning in CLIL classrooms (pp. 105-124). John Benjamins. https://doi.org/10.1075/aals.7.06nik

Nikula, T., Dafouz, E., Moore, P., \& Smit, U. (2016). Conceptualising integration in CLIL and multilingual education. Multilingual Matters. https://doi.org/10.1075/aals.7.06nik

Pawlak, M., \& Oxford, R. L. (2018). Conclusion: The future of research into language learning strategies [Special issue]. Studies in Second Language Learning and Teaching, 8(2), 525-535. https://doi.org/10.14746/ssllt.2018.8.2.15

Piaget, J. (1929). The child's conception of the world. Routledge \& K. Paul.

Plonsky, L. (2011). The effectiveness of second language strategy instruction: A meta-analysis. Language Learning, 61(4), 993-1038. https://doi.org/10.1111/j.1467-9922.2011.00663

O’Malley, M., \& Chamot, A. U. (1990). Language learning strategies in second language acquisition. Cambridge University Press. https://doi.org/10.1017/CBO9781139524490

Oxford, R. L. (1990). Language learning strategies: What every teacher should know. Heinle \& Heinle.

Oxford, R. L. (2017). Teaching and researching language learning strategies: Self-regulation in context (2nd ed). Routledge. https://doi.org/10.4324/9781315719146

Reitbauer, M., Fürstenberg, U., Kletzenbauer, P., \& Marko, K. (2018). Towards a cognitive linguistic turn in CLIL: Unfolding integration. Latin American Journal of Content \& Language Integrated Learning, 11(1), 87-107. https://doi.org/10.5294/lacli1.2018.11.1.5

Rubin, J. (2003). Diary writing as a process: Simple, useful, powerful. Guidelines, 25(2), 10-14. https://doi.org/10.1017/S0958344000003244 
Ruiz de Zarobe, Y. (2015). Basque Country: Plurilingual education. In P. Mehisto \& F. Genesee (Eds.), Building bilingual education systems: Forces, mechanisms and counterweights (pp. 97-108). Cambridge University Press. https://doi.org/10.1007/978-94-011-4531-2_10

Ruiz de Zarobe, Y., \& Cenoz, V. (2015). Way forward in the twenty-first century in content-based instruction: Moving towards integration. Language, Culture and Curriculum, 28(1), 90-96. https://doi.org/10.1080/07908318.2014.1000927

Ruiz de Zarobe, Y., \& Jiménez Catalán, R. M. (2009). Content and language integrated learning: Evidence from research in Europe. Multilingual Matters. https://doi.org/10.21832/9781847691675

Ruiz de Zarobe, Y., Sierra, J. M., \& Gallardo, F. (2011). Content and foreign language integrated learning: Contributions to multilingualism in European contexts. Peter Lang. https://doi.org/10.3726/9783-0351-0171-3

Ruiz de Zarobe, Y., \& Zenotz, V. (2015). Reading strategies and CLIL: The effect of training in formal instruction. The Language Learning Journal, 43(3), 319-333. https://doi.org/10.1080/09571736.2015.1053284

Ruiz de Zarobe, Y., \& Zenotz, V. (2018). Learning strategies in CLIL classrooms: How does strategy instruction affect reading competence over time? International Journal of Bilingual Education and Bilingualism, 21(3), 319-331. https://doi.org/10.1080/13670050.2017.1391745

Schraw, G., \& Dennison, R. S. (1994). Assessing metacognitive awareness. Contemporary Educational Psychology, 19(4), 460-475. https://doi.org/10.1006/ceps.1994.1033

Sheorey, R., \& Mokhtary, K. (2001). Differences in the metacognitive awareness of reading strategies among native and non-native readers. System, 29(4), 431-449. https://doi.org/10.1016/S0346$\underline{251 X(01) 00039-2}$

Smala, S. (2013). CLIL pedagogies in Queensland. International Journal of Pedagogies and
Learning, 8(3), 194-205.

https://doi.org/10.5172/ijpl.2013.8.3.194

Smala, S. (2014). Sole fighter mentality: Stakeholder agency in CLIL programmes in Queensland. The Language Learning Journal, 42(2), 195-208. https://doi.org/10.1080/09571736.2014.889510

Smala, S. (2016). CLIL in Queensland: the evolution of 'immersion'. Babel: Journal of the Australian Federation of Modern Language Teachers' Associations, 50(2/3), 20-27.

Snow, M. A., \& Brinton, D. M. (2017). The content-based classroom: New perspectives on integrating language and content (2nd ed.). University of Michigan Press. https://doi.org/10.3998/mpub.8198148

Stohler, U. (2006). The acquisition of knowledge in bilingual learning: An empirical study on the role of content in language learning. VIEWZ (Vienna English Working Papers), 15(3), 41-46.

Sweller, J. (1988). Cognitive load during problem solving: Effects on learning. Cognitive Science, 12(2), 257-285. https://doi.org/10.1207/s15516709cog1202_4

Ting, T. (2011). CLIL ... not only not immersion but also more than the sum of its parts. ELT Journal, 65(3), 314-317. https://doi.org/10.1093/elt/ccr026

Turner, M. (2018). Teacher legitimisation through language(s) use: Towards a framework for language teacher education, The Language Learning Journal, 46(4), 430-441. https://doi.org/10.1080/09571736.2016.1172329

Van Kampen, E., Admiraal, W., \& Berry, A. (2018). Content and language integrated learning in the Netherlands: Teachers' self-reported pedagogical practices. International Journal of Bilingual Education and Bilingualism, 21(2), 222-236. https://doi.org/10.1080/13670050.2016.1154004

Veenman, M., Prins, F., \& Elshout, J. (2002). Initial inductive learning in a complex computer simulated environment: The role of metacognitive skills and intellectual ability. Computers in Human 
Behavior, 18(3), 327-341.

https://doi.org/10.1016/S0747-5632(01)00038-3

Vollmer, H.-J. (2008). Constructing tasks for content and language integrated learning and assessment. In J. Eckerth \& S. Siekmann (Eds.), Task-based language learning and teaching theoretical, methodological, and pedagogical perspectives (pp. 227-290). Peter Lang.

Watkins, K. E. (2005). "What would be different if higher educational institutions were learning organizations? Advances in Developing Human Resources, 7(3), 414-422. https://doi.org/10.1177/1523422305277179

Webb, P. (2010). Science education and literacy: Imperatives for the developed and developing world. Science, 328, 448-450.

https://doi.org/10.1126/science.1182596

Zhang, L. J. (2010). A dynamic metacognitive system account of Chinese university students' knowledge about EFL reading. TESOL Quarterly, 44(2), 320352. https://doi.org/10.5054/tq.2010.223352

Zhou, Y., \& Wei, M. (2018). Strategies in technologyenhanced language learning. Studies in Second Language Learning and Teaching, 8(2), 471-495. https://doi.org/10.14746/ssllt.2018.8.2.13

Zydatiß, W. (2007). Bilingualer Fachunterricht in Deutschland: eine Bilanz. Fremdsprachen Lehren und Lernen, 36, 8-25. 